\title{
Low-cost method of turbidity estimation using a smartphone application in Cirebon waters, Indonesia
}

\section{Khalid Haidar Dzar Al-Ghifari1 ${ }^{*}$, Susanna Nurdjaman,2, Syarifudin Nur'1, Brian Dika Praba P Cahya1, Destika Agustina Widiawan ${ }^{1}$ and Afif Prabowo Jatiandana ${ }^{1}$}

\author{
${ }^{1}$ Earth Science Master Program, Bandung Institute of Technology, Bandung, West Java, Indonesia \\ ${ }^{2}$ Department of Oceanography, Faculty of Earth Sciences and Technology, Bandung Institute of Technology, \\ Bandung, WestJava, Indonesia
}

*Corresponding author: khalidalghifari1@gmail.com

\begin{abstract}
Coastal conditions are closely related to the conditions of rivers and estuaries in the region, and changes in the river condition caused by human activities will affect water turbidity. River discharge which carries suspended materials and pollutants to the sea has an important role in affecting Cirebon Water turbidity. The aim of this study was to estimate turbidity using a smartphone application called HydroColor. The study data were obtained on 6 September 2020. This study used Horiba U-10 and HydroColor as a method to obtain the turbidity data of Cirebon Water. HydroColor is an advanced technology that can be used to estimate water turbidity. The estimation method using HydroColor is a low-cost method because it only requires a gray card and a HydroColor that is available for iOS and Androidfor free. HydroColor uses a camera on a smartphone as a 3-band radiometer and produces reflectance values measured by HydroColor. Horiba U-10 data is used as in situ data and is compared to HydroColor data to obtain a correlation between the two data sets. The results show that the correlation of HydroColor data with in situ data is 0.91 with p-value lower than 0.05 . HydroColor tends to produce lower turbidity values than the in situ measurement. Spatially, the highest turbidity is found in areas close to the coastline, especially in the western area near Sukalila River and the turbidity value decreases with increasing distance from the sea.
\end{abstract}

Keywords: Cirebon waters, HydroColor, Low-cost, Smartphone, Turbidity

\section{Introduction}

Turbidity is an important water quality parameter that can be used to represent water clarity (Güttler et al., 2013). Turbidity is an optical property of water that measures the reduction of light intensity as it passes through the water column (Swenson and Baldwin, 1965). Reduction in light intensity can be caused by matters suspended in the water which are insoluble organic or inorganic materials such as clay, silt and sand, industrial or household waste discharged by the rivers (Swenson and Baldwin, 1965). This will affect water turbidity at the coastal areas because water conditions are easily affected by rivers and estuaries in the region (Suhartono, 2009). Changes in the water turbidity can have an important effect on the continuity of life of fauna and biota that live in the waters. High turbidity can result in a decrease in water productivity (Cloern et al., 1983), and influence photosynthetic processes in the water (Flemer, 1970). In addition, turbidity can also be used as an indicator of water pollution (Petus et al., 2010).

HydroColor is an application that can measure water turbidity through the remote sensing reflectance of water which is used to estimate water turbidity. To use HydroColor, a smartphone and a photographer's gray card are needed. The smartphone required for measurements using the HydroColor must be equipped with a digital color camera, compass, gyroscope, built-in global positioning system (GPS) and an internet connection. These components can be obtained easily because they are standard components of modern smartphones. Digital cameras are used to capture red, green, and blue bands to estimate the turbidity of water which then are compared with a precise radiometer (Leeuw and Boss 2018). This study aims to estimate turbidity using the HydroColor application and compare it with field observation data.

\section{Study Site}

The coastal area of Cirebon is divided into two administrative zones, namely the Cirebon City and Cirebon Regency. The city of Cirebon has a land use that is dominated by residential blocks but its coastline is dominated by ponds and ports. There are also agricultural and industrial areas covering a significant area of Cirebon City. The coastline of Cirebon Regency is generally formed from mud deposits, especially in the western and eastern parts, but the coast of Cirebon City is dominated by sand substrate (Setyadi and Aryanto, 2008). Cirebon waters have a shape of an open bay to the Java Sea with a relatively shallow depth $(<12$ meters $)$. Abrasion phenomenon was found close to the mouth of the Kalijaga River, namely in the Mundu sub-district. This also 
happens in the eastern area of Cirebon waters, precisely in the Losari Sub-district (Heriati and Husrin, 2018). However, in general, the sedimentation process occurs in almost all northern areas of Cirebon Waters (Widiawaty, 2019).

\section{Materials and Methods}

Cirebon waters have rivers that flow from industrial areas and fishponds. Field data collection was carried out on 6 September 2020 in Cirebon waters in a time range from 08.00 to 15.00 . This time range was chosen to gain an angle of $\pm 135^{\circ}$ from the plane of the sun for optimal data collection as angle differences can affect reflection readings. Data was taken on a fair-weather condition.

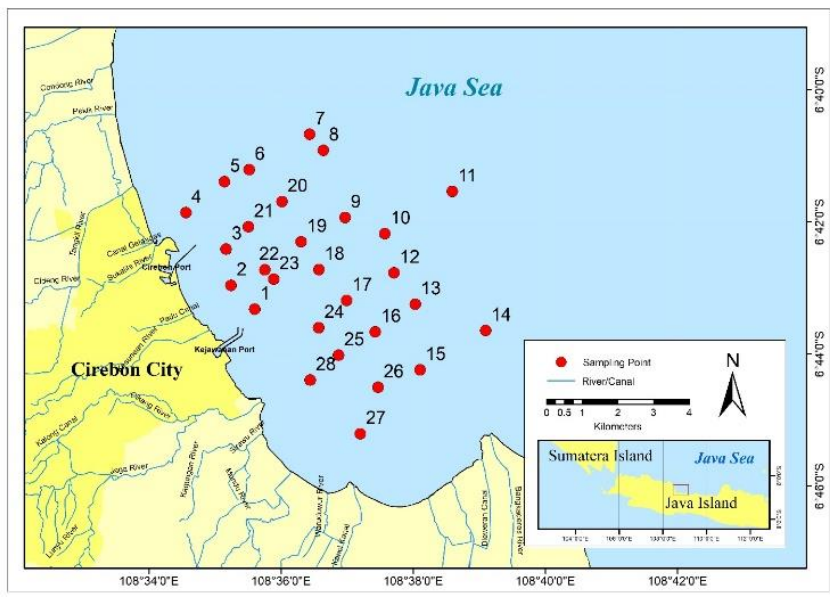

Figure 1. Turbidity data retrieval from Cirebon waters.

There are 28 points of observation data collection for surface turbidity (depth of $1 \mathrm{~m}$ ) using Horiba U-10 and HydroColor estimation taken through a smartphone.

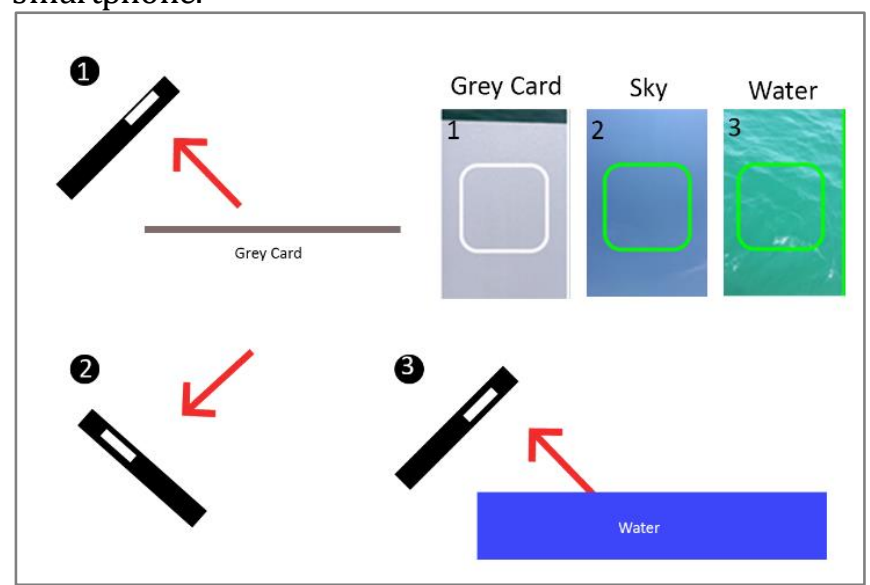

Figure 2. The procedure of data retrieval by HydroColor application. The image of the gray card is taken at $40^{\circ}$ from the nadir point and $135^{\circ}$ from the sun, while the image of the sky is taken at $130^{\circ}$ from the nadir point and $135^{\circ}$ from the sun. The image of water is taken at $40^{\circ}$ from the nadir point and $135^{\circ}$ degrees from the sun. The three images are taken consecutively (Leeuw and Boss, 2018).
All the observation points comprised both surface turbidity and HydroColor data. Horiba U-10 has a range from 0-800 NTU and a sensitivity of 1 NTU. These qualities are enough to be compared with HydroColor as the application has a sensitivity of 1 NTU. HydroColor data were taken using the Samsung A6 + smartphone which has a camera resolution of $16 \mathrm{MP}, \mathrm{f} / 1.7,26 \mathrm{~mm}$.

\section{Results and Discussion}

Figure 3 shows that the HydroColor data has a pattern similar to the observation data. The same is shown by the red reflectance. Compared to the green and blue reflectance, the red reflectance has a pattern that is more similar to the observed data. Although some data show a similar pattern to the observation data, there is a slight difference in the data values at some stations. Most of the turbidity produced by HydroColor is either the same or lower than the observed data. The only contrast is shown in the first 4 stations, where HydroColor estimation value exceeded observation data. The similarity between the red reflectance pattern and field turbidity and HydroColor is also evident from Figure 4 which has simplified the stations into 3 categories. This figure also shows that the turbidity decreases as the distance from coastline increases. The lowest average turbidity is found in offshore waters. The distribution of observation data and HydroColor can be seen in the scatterplot of Figure 5. This figure shows a positive relationship. Note that the scatterplot only suggests the relationship between the HydroColor and observation data.

Table 1 shows that the observation and HydroColor data produce a good correlation value (0.91) which indicated a strong relationship between observation and HydroColor turbidity. HydroColor data also indicated p-values lower than 0.05 suggesting statistical significance except for blue reflectance where $P$ value is 0.2 . In addition, red reflectance has the highest correlation value compared to the other reflectance (0.89), which indicated a strong relationship with observation turbidity. The greater the value of red reflectance means the greater the estimated turbidity and vice-versa. Green reflectance has a lower correlation value, while blue reflectance has the lowest correlation value. High correlation results of HydroColor turbidity and red reflectance portrayed how well the algorithm used by Leeuw and Boss (2018) worked to produce HydroColor turbidity that can be compared to field data. This study shows a higher correlation of HydroColor data with observation data and the results obtained by Mahama (2016) and Ouma et al. (2018) where correlations were 0.68 and 0.70 , respectively. This difference can be caused by differences in particle size distribution in the waters (Neukermans et al., 2012). 


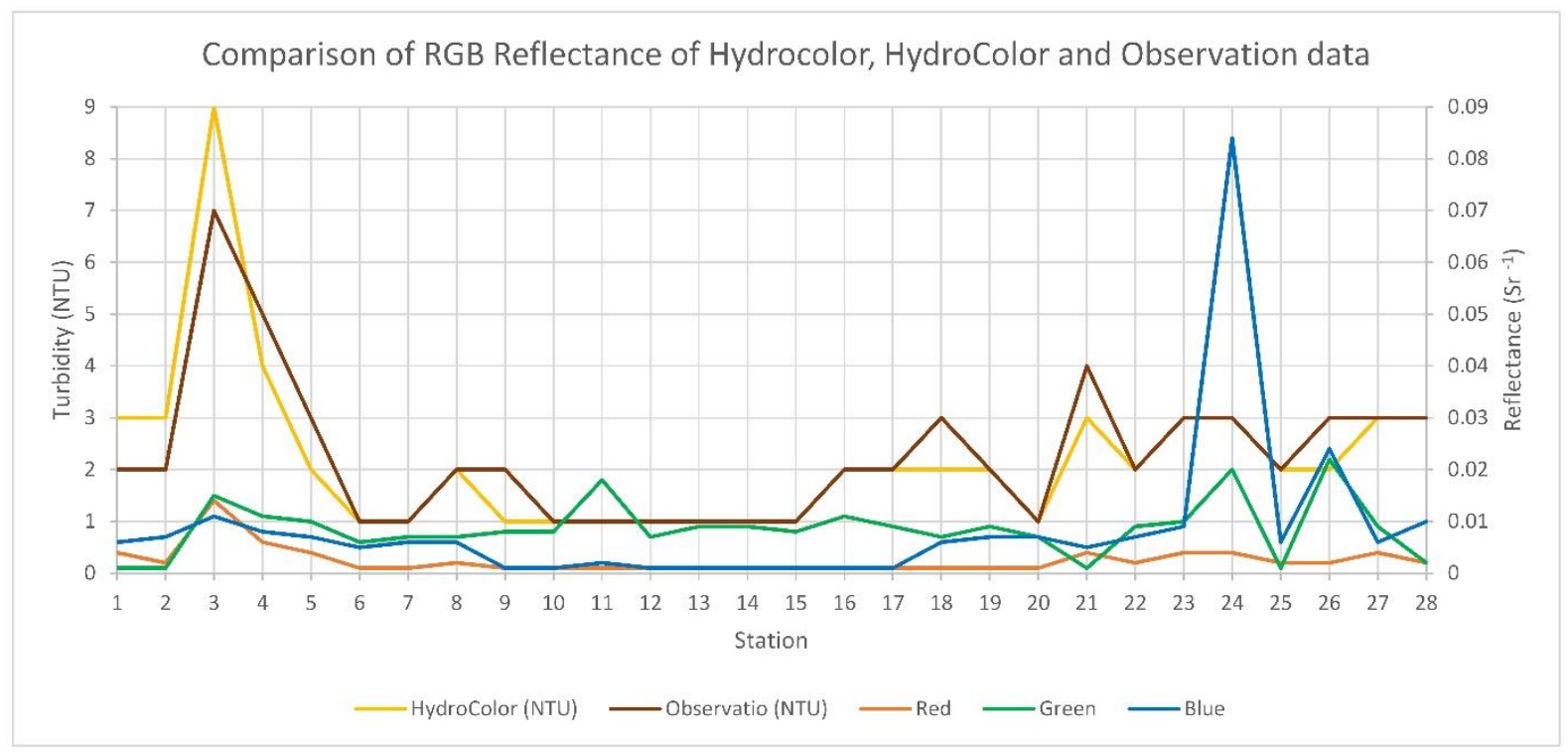

Figure 3. Line graph of observation, HydroColor turbidity data and red, green and blue reflectance values of every station.

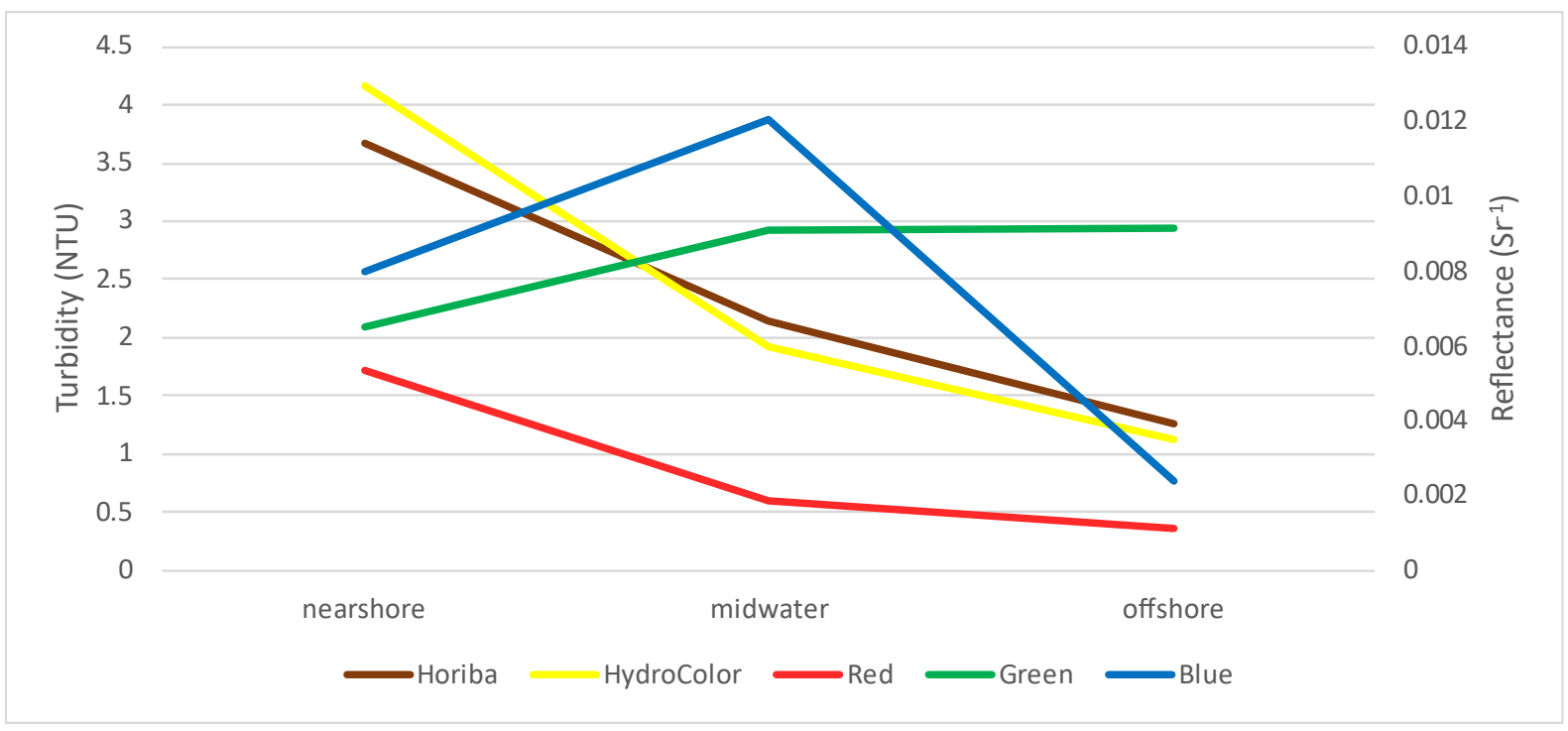

Figure 4. Line graph of observation, HydroColor turbidity data and red, green and blue reflectance values of every nearshore (station 1, 2, 3, 4, 27 and 28), midwater (station 5, 6, and 15 to 26) and offshore (station 7 to 14) stations. 


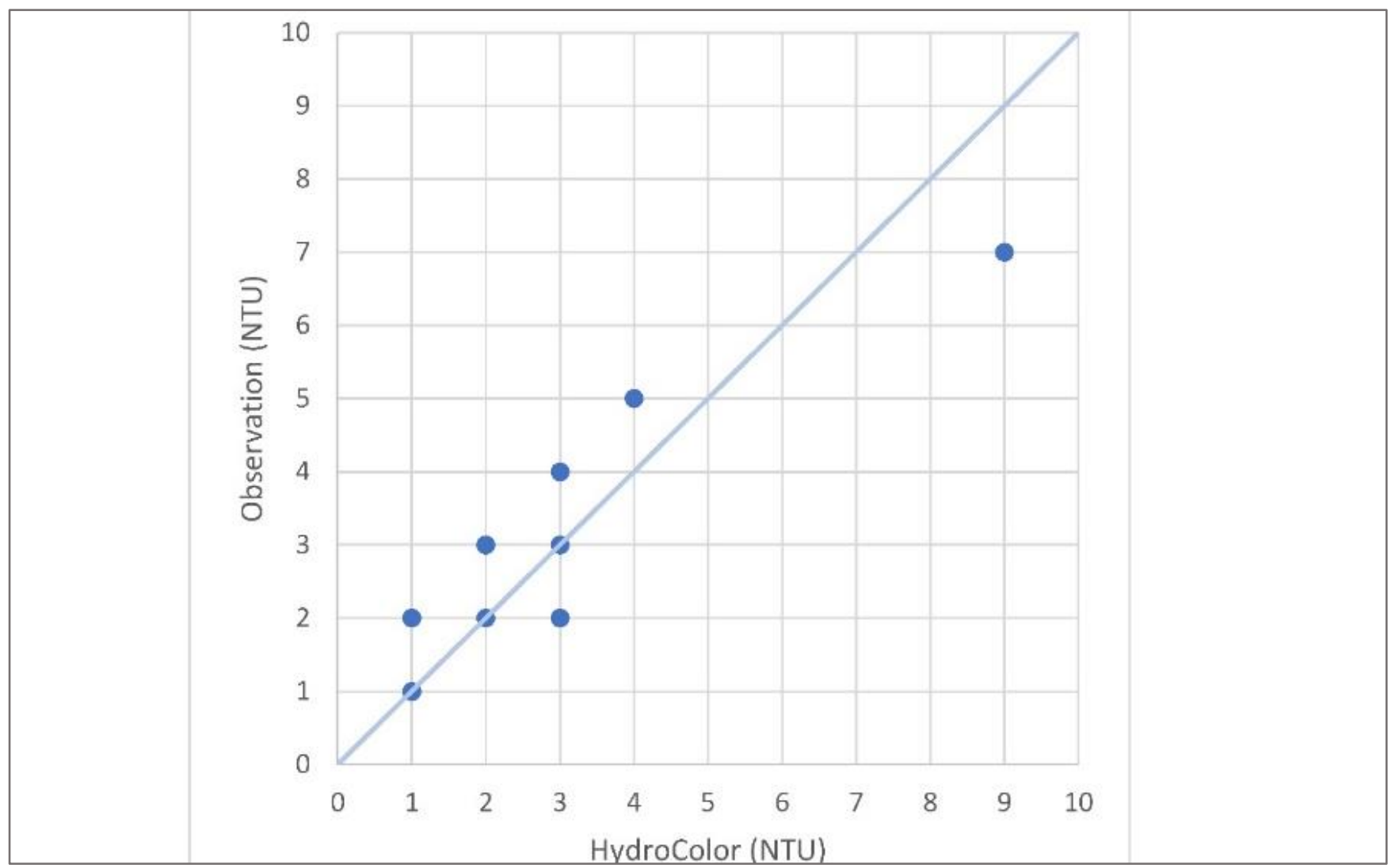

Figure 5. Turbidity scatterplot.

Table 1. Correlation of hydrocolor data with observation turbidity.

\begin{tabular}{lll}
\hline & Correlation & $\mathrm{p}$-value \\
\hline Red Reflectance & 0.89 & 0.0000000004 \\
Green Reflectance & 0.75 & 0.0000037555 \\
Blue Reflectance & 0.25 & 0.2086570675 \\
HydroColor Turbidity & 0.91 & 0.00000000002 \\
\hline
\end{tabular}

The turbidity contours of Figure 6 demonstrate that the highest turbidity is found near the coast and the lowest in areas far from the coast. In the western area close to the coastline, the contours are of darker red colour, indicating a drastic increase in turbidity. Observation data recorded the highest turbidity data close to the coastline which reached up to 7 NTU. As the distance from the coastline increases, water turbidity decreases with the lowest value recorded in the furthest area from the coastline. In that area, turbidity could reach as low as 1 NTU and can be seen homogeneous at a distance of about $7 \mathrm{~km}$ from the coastline. This low turbidity is due to the fact that this area is quite far from the river outlet where the effect of river discharge is lower. Earlier investigations also documented a close relationship between turbidity and the hydrological condition of a river (Constantin et al., 2016).

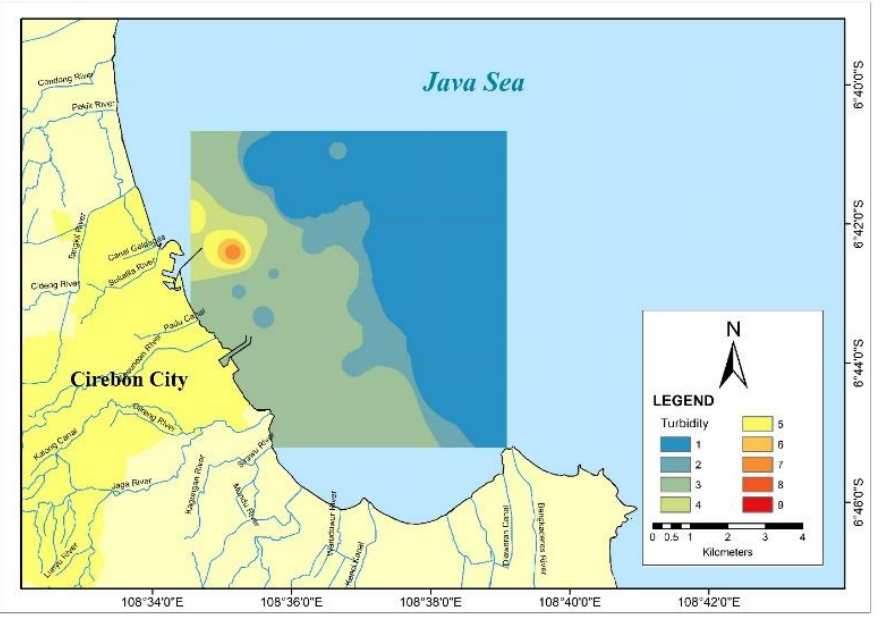

Figure 6. Turbidity (observation data) distribution map of Cirebon waters.

Figure 7 shows the pattern of turbidity distribution using HydroColor data. The distribution pattern of HydroColor turbidity data is similar to the observation data, but HydroColor data shows that the eastern part of the water is dominated by a turbidity value of 2 NTU, slightly lower than the observed data. Similar to the observational data, the HydroColor data shows high turbidity in the western part of the water. 


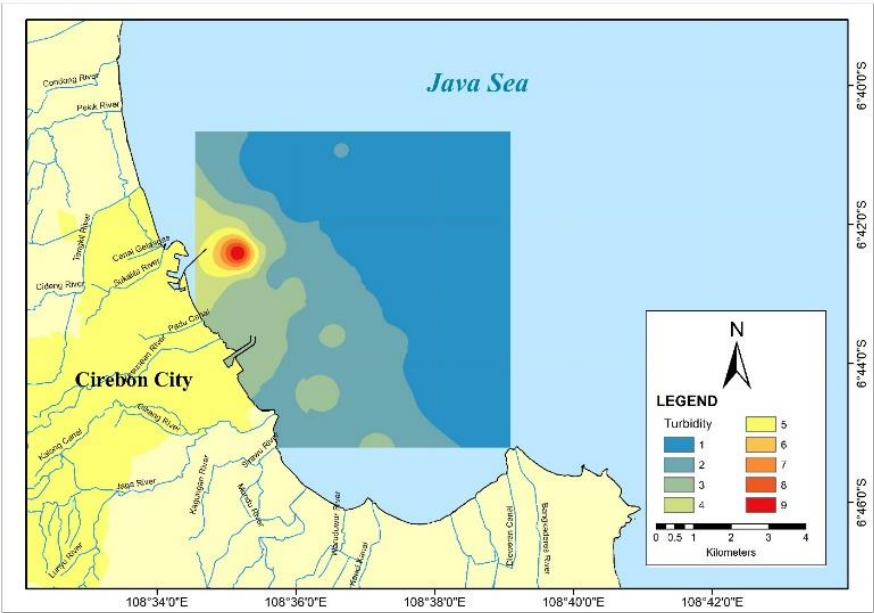

Figure 7. Turbidity (hydrocolor data) distribution map of Cirebon waters.

The high turbidity value can be caused by Sukalila River as it play a major role in increasing water turbidity (Constantin et al. 2016). Rivers carry inorganic and organic materials which can increase in quantity over time (Swenson and Baldwin, 1965). In addition, this location is close to Cirebon Port where some activities related to the port operations and uses may influence the water turbidity.

\section{Conclusion}

It can be concluded that the turbidity estimation results obtained using HydroColor data have a correlation of 0.91 when compared with the observation data. The red reflectance has the greatest correlation among other reflectance, which is 0.89 . HydroColor generally produces lower values than in situ values. The HydroColor data produces a distribution pattern similar to the observational data. In general, high turbidity is found in areas close to the coastline and the turbidity value decreases with increasing distance from the coast. The two turbidity distribution maps show high turbidity in the western area near the Sukalila River.

\section{Acknowledgments}

This research was supported by the project "Marine Science \& Technology Cooperation between Korea and Indonesia (20180319)" funded by the Ministry of Oceans and Fisheries, Korea.

\section{References}

Cloern, J. E., Alpine, A. E., Cole, B. E., Wong, R. L. J., Arthur, J. F., \& Ball, M. D. (1983). River discharge controls phytoplankton dynamics in the northern San Francisco Bay Estuary. Deep Sea Research Part B. Oceanographic Literature Review 16, 415-429.

Constantin, S., Doxaran, D., \& Constantinescu, S. (2016). Estimation of water turbidity and analysis of its spatio-temporal variability in the Danube River plume (Black Sea) using MODIS satellite data. Continental Shelf Research 112, 14-30.

Flemer, D. A. (1970). Primary production in the Chesapeake Bay. Chesapeake Science 11(2), 117-129.

Güttler, F. N., Niculescu, S., \& Gohin, F. (2013). Turbidity retrieval and monitoring of Danube Delta waters using multi-sensor optical remote sensing data: An integrated view from the delta plain lakes to the western-northwestern Black Sea coastal zone. Remote Sensing of Environment 132, 86-101.

Heriati, A., \& Husrin, S. (2018). Perubahan garis pantai di Pesisir Cireb on berdasarkan analisis spasial. Reka Geomatika 2017(2), 52-60.

Leeuw, T., \& Boss, E. (2018). The HydroColor app: Above water measurements of remote sensing reflectance and turbidity using a smartphone camera. Sensors 18(1), 256.

Mahama, P. N. (2016). Assessment of the utility of smartphones for water quality monitoring. University of Twente, Enschede, Netherlands.

Neukermans, G., Loisel, H., Me, X., Astoreca, R., \& Mckee, D. (2012). In situ variability of mass-specific beam attenuation and backscattering of marine particles with respect to particle size, density, and composition. Limnology and Oceanography 57 (1), 124-144.

O uma, Y. O., Waga, J., Okech, M., Lavisa, O., \& Mbuthia, D. (2018) Estimation of reservoir bio-optical water quality parameters using smartphone sensor apps and Landsat ETM+: Review and comparative experimental results. Journal of Sensors 2018, 1-32.

Petus, C., Chust, G., Gohin, F., Doxaran, D., Froidefond, J. M., \& Sagarminaga, Y. (2010). Estimating turbidity and total suspended matter in the Adour River plume (South Bay of Biscay) using MODIS 250 $m$ imagery. Continental Shelf Research 30(5), 379-392.

Setyadi, D., \& Aryanto, N. C. (2008). Proses pendangkalan di pantai dan lepas pantai Cirebon akibat laju sedimentasi asal daratan yang tinggi. Jurnal Geologi Dan Sumberdaya Mineral 18(5), 299-307.

Suhartono, E. (2009). Identifikasi kualitas perairan pantai akibat limbah domestik pada Monsun Timur dengan metode indeks pencemaran (Studi kasus di Jakarta, Semarang dan Jepara). Jurnal Pengembangan Teknik Sipil, 14, 51-62.

Swenson, H. A., \& Baldwin, H. L. (1965). A primer on water quality. In General Interest Publication, Washington, USA.

Widiawaty, M. A. (2019). Upaya konservasi dan rehabilitasi pada kawasan tanah timbul (Aanslibbing): Studi kasus pesisir Utara Cirebon Timur. Panduan Teknis Konservasi dan Rehabilitasi sebagai Upaya Menyelamatkan Lahan, 36-45. 